course of ages have been gradually acclimated by artificial dissemination, and not the fragments of a flora derived from Arctic regions. Granting this, then the same method would apply to Clematis Virginiana, Negundo aceroides, Ampelopsis quinquefolia, Prunus (Cerasus) serotina, Cornus, Shepherdia argentea, Sambucus pubens, Hypopitys; all found according to Richardson far north in the British possessions, within the old buffalo range, but also common as far south as latitude $35^{\circ}$ north.

Golden, Colorado.

\title{
Notes on certain species of Erythronium.
}

E. B. KNERR.

Perhaps there is no more interesting genus of plants among Liliaceæ than Erythronium. The species are the first of the order to appear in the spring and in point of beauty are second to none. Besides, there are features of propagation quite as puzzling and wonderful as any to be found.

Of the three species to be mentioned E. Americanum Ker. is the most common in the eastern states, E. albidum Nutt. in the central and western states to Kansas and Nebraska, while E. mesochoreum Knerr belongs to the states of the lower Missouri valley. All three species present two kinds of plants: a flowering two-leaved and a flowerless one-leaved form, both of which arise from underground corms. In the flowering forms these corms, or rather fleshy bulbs, consist of a series of corms arranged somewhat spirally one within the other, sometimes as many as four or five in number, the youngest innermost, each corm producing its plant in succession a year apart and beginning with the oldest and outermost. Sometimes, however, in E. mesochoreum and E. Americanum it happens that two and even three of these corms may develop at once, producing as many leafy scapes apparently from the same root, when ordinarily but one would be expected. As yet I have never noticed this in E. albidum.

The sterile forms (one-leaved) both of E. Americanum and E. albidum, and sometimes the flowering, send out underground off-shoots or rhizomes which produce at their extremities new corms destined to furnish the plants of the next season. In the two species, however, there is this difference: 
E. albidum usually sends out but two (though sometimes specimens are found with but one such rhizome), a strong vigorous one and a second that is weaker and smaller. In $\mathrm{E}$. Americanum the number is usually from three to five, successively diminishing in size, all more or less coiled and twisted. In E. albidum they are much straighter and somewhat deeper rooted. E. mesochoreum never produces such rhizomes, so far as we have observed, either in the one-leaved or in the twoleaved forms.

Herein we readily find an explanation for the multitude of the one-leaved forms of both E. albidum and E. Americanum wherever they occur; for in the case of the first species where this year was but one plant, next year will be two; and in the case of the second species even a greater number will appear, a plant for each new rhizome. Thus it is that whole slopes of shaded ravines become carpeted with these beautifully mottled leaves. Only one here and there of the thousands is destined to develop a corm without offshoots, which in a season or two may send up a flowering scape to produce seed and propagate its species sexually.

Right here arises an interesting question: What selective power is it that determines the one in the ten thousand, which is thus to reach fruiting?

We are reminded that this same question arises in other branches of biology wherever propagation is secured by both the asexual and the sexual processes. The reply usually given is that the conditions lie in the food supply, a very plausible answer for the most part, but we seriously. doubt its sufficiency.

As such rhizomes producing corms at their extremities are entirely wanting in E. mesochoreum, sterile forms in this species are comparatively rare, and those that do occur are seedlings soon to become fertile flowering forms. Hence it is that where this plant is established there is no lack of bloom in the flowering season.

The leaves of E. albidum and E. Americanum are very similar in appearance, being both very conspicuously mottled with various shades of green and purple, especially in the early part of their blooming season; but those of the latter species are usually broader and flatter than those of the former. We have noticed that this mottling disappears to a great extent, especially in E. albidum, as the season advances, the color be- 
coming almost a uniform bright green and then fading to yellow as the leaves wither. But as yet we have sought in vain for unmottled forms of young $\mathrm{E}$. albidum mentioned in the botanies. The third species, E. mesochoreum is never mottled, especially when young, though we have found a few specimens that showed a faint mottling in lighter shades of green when the season was much advanced. The leaves of this species are also much narrower and longer than those of either the other two, being mostly linear-lanceolate, and indeed even linear in some specimens.

The habitat of these plants is also characteristic, E. albidum and E. Americanum preferring deep shaded ravines and moist meadows, while E. mesochoreum takes to the hill-tops and the north facing slopes whether wooded, or open and covered with grass.

The color of the sepals is also distinctive, E. Americanum being yellow with purple dots at the base, E. albidum white tinged with pink, and E. mesochoreum also white, but tinged with lavender or blue. The perianth of the last is usually much longer than that of E. albidum and is not so much reflexed in the bright sunshine.

The stigmas of E. Americanum are peculiar, being massed into a club-shaped body; those of $\mathrm{E}$. albidum are quite divergent and somewhat recurved; while in E. mesochoreum they are more slender and decidedly recurved. The capsules of this last species are also much larger and longer than those of either the other two and everything indicates that the seed is also more vigorous, a fact naturally to be expected, seeing that this form propagates rather sparingly by the bulb.

Midland College, Atchison, Kansas.

\section{BRIEFER ARTICLES.}

Notes upon Daueus Carota. ${ }^{1}$ - The early'introduction of this plant, from its European soil and environments, and its present wide distribution, and ready adaptation to new conditions make it a good type from which to expect those variations of habit, structure, etc., which usually attend the transplanting of a new organism with new conditions. Records of the numerous changes which it has undergone

${ }^{1}$ Read before Section F, A. A. A. S., Rochester meeting, August, 1892 . 


\section{$2 \mathrm{BHL}$ Biodiversity Heritage Library}

Knerr, E B . 1892. "Notes on Certain Species of Erythronium." Botanical gazette 17(10), 326-328. https://doi.org/10.1086/326849.

View This Item Online: $\underline{\text { https://www.biodiversitylibrary.org/item/92733 }}$

DOI: https://doi.org/10.1086/326849

Permalink: https://www.biodiversitylibrary.org/partpdf/222190

\section{Holding Institution}

Missouri Botanical Garden, Peter H. Raven Library

\section{Sponsored by}

Missouri Botanical Garden

\section{Copyright \& Reuse}

Copyright Status: Public domain. The BHL considers that this work is no longer under copyright protection.

This document was created from content at the Biodiversity Heritage Library, the world's largest open access digital library for biodiversity literature and archives. Visit BHL at https://www.biodiversitylibrary.org. 